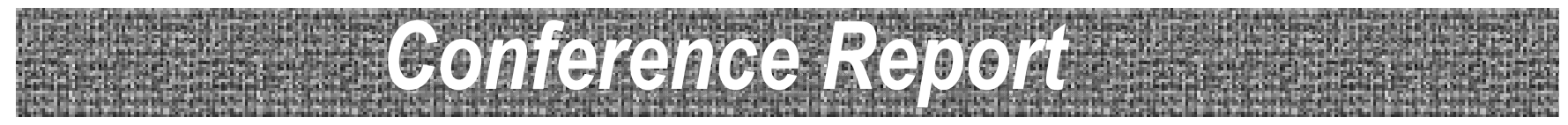

学界情報 国際会議レポート

\title{
International Conference on MECHATRONICS (ICM 2017), February 13-15, 2017, Australia, Gippsland
}

2017 年 2 月 13 日から 15 日までの 3 日間, International Conference on Mechatronics (ICM) 2017 が開催された。ICM は IEEEの Industrial Electronics Society (IES) が主催する国 際会議であり, 隔年で開催されている。2013 年はイタリア, 2015 年は名古屋で開催され, 2017 年はオーストラリア Gippsland の Federation University が会場となった。

ICM2017では, Robotics and Motion Control, Sensors and Actuators, Industrial Cyber-Physical Systems, MEMS and Nanotechnologies, Autonomous System, Innovative Vehicle Technologies をはじめ, メカトロニクスに関連する様々な 研究報告がなされた。図 1 は Technical Tracks と Special Sessions における第一著者の国籍の内訳である。ICM2017 では，延べ 18 力国から 76 稿の論文投稿があった。

会場の Federation Universityへの道のりはメルボルン空港 から高速バスでメルボルン市街へ行き, V-Line という高速 鉄道に乗り東へ約 2 時間, そしてローカルバスを乗り継い でやっとたどり着くという, 海外経験の浅い私には少々八 ードルの高い道のりであったが，無事に広大な自然に囲ま れた Federation Universityの Gippsland キャンパスにたどり 着くことができた。

2 日目のバンケットは, 大学よりさらに奥地にある Bonnie Brae という農場の壮大な自然に囲まれた丘の上に ある小屋で行われた。最初にウェルカムパーティーが小屋 の外で行われ, オーストラリアワインを片手に, 隣には放 牧された牛の群れとそれを追いかけるムチを持ったお姉さ ん, ワニやへビなどの爬虫類のお出迎えもあり, 非常に賑 やかなものになった（図 2)。日が暮れ始めると, 牛を追い かけていたお姉さんの少々過激な（?）合図で一同は小屋 の中へ。中では豪華ディナーとバンドの演奏が用意されて いて，素晴らしい雰囲気の中での食事となった。バンケッ 卜終盤には会場の一部がダンスによる国際交流の場になっ たり (図 3), 外に出れば満点の星空と, まさにオーストラ リアの素晴らしさを満喫できる夜となった。

3 日目の基調講演では “Soft Robotics - A Key Concept of Mechatronics” と題し, 慶應義塾大学の大西元会長より今後 のメカトロニクスに対する貴重な提言がなされた。特に著 者が印象に残ったのは, 数字的に裏付けされた「今後のロ ボット市場は工場内ではなく家庭内にある」という提言で あった。FA 関連の機械を扱っている当社としては, 従来の 枠に捉われない変革が必要であるということを改めて痛感 させられた。全体を通じても実に様々な研究報告があり， 今後の研究に向けて, 知見や発想を広げる大変貴重な機会 となった。

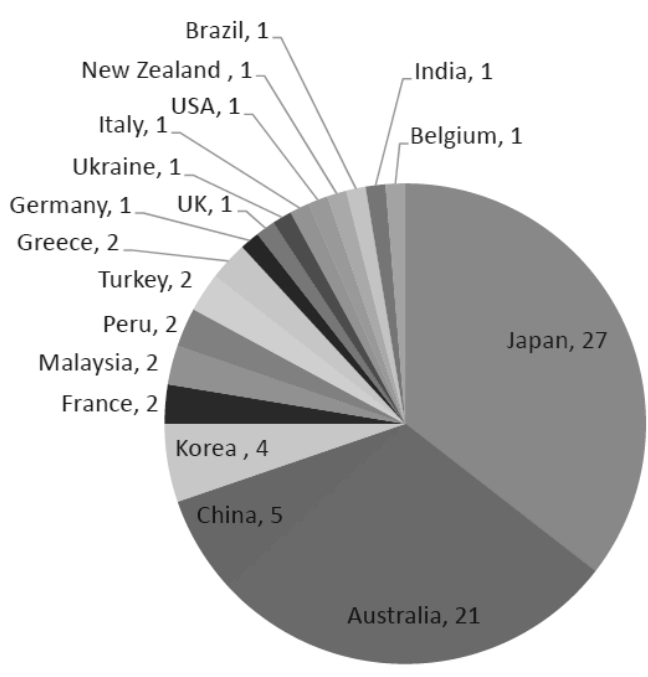

図 1 第一著者の国籍の内訳

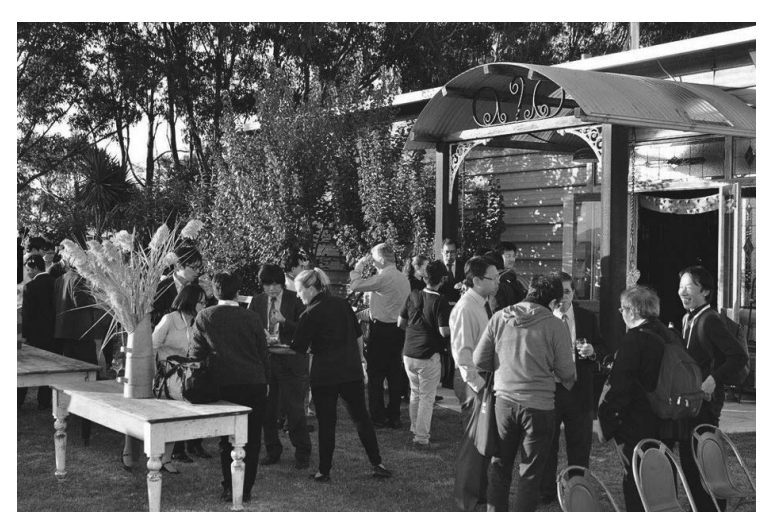

図 2 バンケットの様子 1

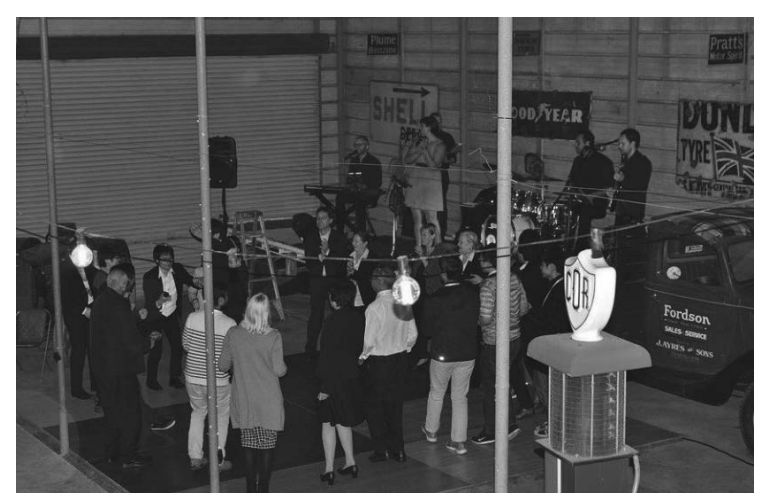

図 3 バンケットの様子 2

竹内 一生（東京自働機械製作所）

(平成 29 年 4 月 28 日受付) 